\title{
建築物の残存確率関数モデルの導出と地域内建物平均老朽度推定への応用 MODELING OF PROBABILITY FUNCTION OF REMAINDER WITH APPLICATIONS TO EVALUATION OF AVERAGE AGE OF BUILDINGS
}

\author{
大佛俊 泰*，鎌田詩 織** \\ Toshihiro OSARAGI and Shiori KAMATA
}

\begin{abstract}
Various research studies about the life span of buildings have been carried out, since the life span of buildings is one of the basic concerns for land use forecast. In this paper, we propose a mathematical model that can stably estimate the value of probability that buildings will be demolished or will remain within the specific time interval. As an application of the model, we propose and examine a method that can estimate the average age of buildings within a district, using time series digital maps taken from densely built-up areas of Tokyo.
\end{abstract}

Keywords: Land Use, Life Span, Demolished Building, Probability Function of Remainder, Reliability Theory 土地利用, 寿命, 除却建築物, 残存確率関数, 信頼性理論

\section{1. はじめに}

建築物の除却・残存性向は，商店街や業務地の趨勢，住環境や市 街地景観など，さまざまな都市活動や都市環境と密接に関係してい る。また，土地利用計画や都市基盤施設整備計画などの都市政策と も関連しており，建築物の除却・残存性向を捉えることは非常に重

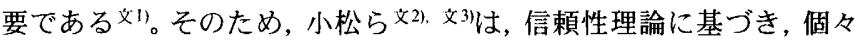
の建築物の築年数と除却・残存に関するデー夕をもとに区間残存確 率を求め, 建築物の残存確率曲線を導いている。また, 堤ら文4は, 平均寿命を推定する方法を提案し，地域や年度による除却・残存性 向の変化を捉えている。また，大佛ら文惊は，小松らの方法を発展さ せ，建築物の属性や立地する場所性などに関する因子が，建築物の 寿命に及ぼす影響を評価する方法を提案している。

しかし, このようにして得られる区間残存確率は, 観測データが 少ない場合には安定的に推定することができず，他の分析に応用す ることは難しい。例えば，次章で詳述するように，建築物の築年数 から具体的な区間残存確率を推定することは困難である。そこで本 研究では, 建築物の除却のされやすさを表現する除却率関数を築年 数の連続関数として定式化し,それをもとに残存確率関数モデル(残 存確率関数, 区間残存確率関数) を安定的に推定する方法を提案す る。さらに, 残存確率関数モデルの具体的な応用例として, 次の分 析を試みる。
近年, 数值地図は急速に高度化しており, 多様な情報が高い精度 で入手可能となった。しかし，建築物の築年数と除却・残存に関す る情報については，一般にはデー夕化されていない。そのため，2 時点の数値地図や航空写真を比較して，除却された建物を抽出する 方法文(6, 建築物の新旧を判断する方法が試みられている。例えば, 三浦ら文》は, 25 年のタイムラグのあるふたつの航空写真を比較する ことで，現存する建築物から老朽化建物を同定し，構造的に建替え が必要とされる老朽度の高い地区を抽出している。本研究では，区 間残存確率関数の応用例のひとつとして，除却された建物の数から 当該地区の老朽度を推定する方法について検討する。

\section{2. 残存確率関数モテルの導出と推定 \\ 2.1 区間残存確率関数の定式化}

建築物の築年数を $t(t>=0)$, 建築物の属性（建物用途, 立地場 所の特性など）を $j(j=1, \ldots, m)$ でそれぞれ表現する。属性 $j$ の新 築の建築物が $t$ 年後まで残存し続ける確率を $P_{j}(t)$ で表し, 築年数 $t$ に関して連続で微分可能な関数之考え「残存確率関数」と呼ぶ。ま た, ある時点 $t$ まで残存していた建築物がその後の単位時間内に除 却される確率を $h_{j}(t)$ で表し, 同様に築年数 $t$ に関して連続で微分可 能な関数と考え「除却率関数」と呼ぶ。さらに, 建築物の寿命の確 率密度関数を $f_{j}(t)$ で表すと, 信頼性理論における基礎的な知見から,

\footnotetext{
* 東京工業大学大学院情報理工学研究科 助教授・博士 (工学)

** 東京工業大学大学院情報理工学研究科 大学院生
}

Assoc. Prof., Graduate School of Information Science and Engineering, Tokyo Institute of Technology, Dr. Eng.

Graduate Student, Graduate School of Information Science and Engineering, Tokyo Institute of Technology 
これらの三つの関数には以下の関倸が成立している文 ${ }^{8)}$

$$
\begin{aligned}
& f_{j}(t)=\frac{-d P_{j}(t)}{d t} \\
& h_{j}(t)=\frac{f_{j}(t)}{P_{j}(t)}
\end{aligned}
$$

ここで, 式(2)を式(1)へ代入して変形すると次式を得る。

$$
P_{j}(t)=\exp \left[-\int_{0}^{t} h_{j}(x) d x\right]
$$

除却率関数 $h_{j}(t)$ の具体的な関数型について吟味することは重要で あるが，ここでは $h_{j}(t)$ の Taylor 展開を考え，次のように記述する。

$$
h_{j}(t) \cong \sum_{k=0}^{K-1} \frac{h_{j}^{(k)}(a)}{k !}(t-a)^{k}
$$

ただし， $h_{j}^{(k)}(a)$ は築年数 $a$ における $h_{j}(t)$ の $k$ 次微分であり, $K$ は近 似に十分な次数である。すなわち, 除却率関数 $h_{j}(t)$ が $t$ の多項式で 記述できると考えると，式(3)は次のように書き換えることができる。

$$
P_{j}(t)=\exp \left[-\sum_{k=1}^{K} a_{j k} t^{k}\right]
$$

ただし， $a_{j k}$ は式(4)における $k$ 次の項に対応する倸数である。ここで, 式(4)の除却率関数 $h_{j}(t)$ と, $a_{j k}$ との対応関係を明確にするために, 式 (4)を $a_{j k}$ を用いて次のように表現しておく。

$$
h_{j}(t)=\sum_{k=1}^{K} k a_{j k} t^{k-1}
$$

次に, 築年数 $t$ まで残存した建築物が, 築年数 $t+\Delta t(\Delta t>0)$ まで 残存し続ける確率を $P_{j}(t+\Delta t \mid t)$ と表現し,「区間残存確率関数」之呼 ぶ。区間残存確率関数 $P_{j}(t+\Delta t \mid t)$ は条件付確率であるので, 式(5)の 残存確率関数 $P_{j}(t)$ を用いれば, 容易に次式を得ることができる。

$$
\begin{aligned}
P_{j}(t+\Delta t \mid t) & =\frac{P_{j}(t+\Delta t)}{P_{j}(t)} \\
& =\exp \left[-\sum_{k=1}^{K} a_{j k}\left\{(t+\Delta t)^{k}-t^{k}\right\}\right]
\end{aligned}
$$

以上より， $a_{j k}$ の值が求まれば，除却率関数，残存確率関数，およ び，区間残存確率関数を得ることができる。

\section{2 残存確率関数パラメータの推定方法}

築年数 $t$ は連続量であるが，本節では実デー夕との対応関係をわ かりやすくするために, 離散的な量 $(t=0,1, \ldots, n)$ と考える。このこ とで一般性は失われない。属性 $j$, 築年数 $t$ の建築物の数を $N_{j}(t)$, そのうち築年数 $t+1$ になるまでに除却される建築物の数を $d_{j}(t)$ とす ると,これらのデー夕が観測される同時確率 $P$ は次式で表される。

$$
\begin{aligned}
P= & \prod_{j=1}^{m} \prod_{t=0}^{n-1} \frac{N_{j}(t) !}{d_{j}(t) !\left\{N_{j}(t)-d_{j}(t)\right\} !} \\
& \cdot\left\{1-P_{j}(t+1 \mid t)\right\}^{d_{j}(t)} P_{j}(t+1 \mid t)^{N_{j}(t)-d_{j}(t)}
\end{aligned}
$$

ただし， $n$ は一番古い建築物の築年数である。ここで, 式(7)の $\Delta t$ を 1 として式(8)に代入し, 同時確率 $P$ をパラメータ $a_{j k}$ だけの関数（尤 度関数）と考えると, $a_{j k}$ の最尤推定量は統計量 $P$ の值を最大とする
值として推定することができる。尤度関数 $P$ の最大化は, その対数 の最大化と等価であるので, ここでは対数尤度関数 $\ln P$ の最大化問 題として考える。

このとき, 残存確率関数 $P_{j}(t)$ と区間残存確率関数 $P_{j}(t+1 \mid t)$ は 1 以 下の值をとり, また, 除却率関数 $h_{j}(t)$ は 0 以上の值をとることから, パラメータ $a_{j k}$ はそれぞれ次の条件を満足しなければならない。

$$
\begin{aligned}
& \sum_{k=1}^{K} a_{j k} t^{k} \geq 0 \quad \text { for all } j, t \\
& \sum_{k=1}^{K} a_{j k}\left\{(t+1)^{k}-t^{k}\right\} \geq 0 \quad \text { for all } j, t \\
& \sum_{k=1}^{K} k a_{j k} t^{k-1} \geq 0 \quad \text { for all } j, t
\end{aligned}
$$

しかし, 式(6)より $h_{j}(0)=0$ であるので, 式(3)から $P_{j}(0)=1$ であり, さらに, もし, $h_{j}(t)>0(t>0)$ であれば $P_{j}(t)$ は単調に隇少すること がわかる。また, $P_{j}(t)$ が $t$ に関して単調減少関数となっていれば, $P_{j}(t+1 \mid t)$ は, 式(7)の定義式から明らかなように, 必ず $P_{j}(t+1 \mid t)<1$ となる。すなわち, 式(11)を满足するパラメー夕 $a_{j k}$ は, 式(9)と式(10) を同時に満足することがわかる。

以下では, 式(11)の制約条件を考慮して, 対数尤度関数 $\ln P$ の最 大化問題をラグランジュの未定乗数法により解くこととする沫1)。こ のとき,ラグランジュ関数のパラメータ $a_{j k}$ に関する 2 階微分は常に 負であるので注， ラグランジュ関数は上に凸である。すなわち，上 記の最大化問題を勾配法などを用いて数值的に解いても局所解の問 題は伴わない。

\section{3 実データを用いたモデル推定と除却率関数の特徽}

以下では, 東京都M市における建築物の築年数と除却・残存に関 するデー夕を用いてパラメー夕 $a_{j k}$ を推定する。ただし，年度によっ て除却・残存性向が大きく異なる可能性があるので文4)，パラメー夕 を安定的に推定するために, 本稿では5年間に観測される除却・残存 のデー夕をもとに分析することとした。具体的には，1993年の固定 資産課税台帳に記載されている情報（建築物の建築年と主用途）を 用いて, まず, 主用途8分類 $(m=8)$ 別にすべての建築物の1993年時 点における築年数を求めた。次に, 1998年の固定資産課税台帳の情 報と照合することで, 各建築物が5年後まで残存していたか, それと も除却されたかを判断した。以上の作業により, 式(8)における観測 データ，すなわち， $N_{j}(t), d_{j}(t)$ を準備することができる。ただし, 第二次世界大戦前後の特異な除却・残存デー夕を排除するために 1953年以降に建設された建築物のデータのみを分析対象とし，また， 延べ面積が $20 \mathrm{~m}^{2}$ 以上の建築物のみを対象とした。さらに,ここでは 5 年間に観測された除却・残存を対象としているので，式(8)におけ る $\mathrm{P}_{j}(t+1 \mid t)$ はP $\mathrm{P}_{j}(t+5 \mid t)$ で置き換える必要がある。同時に, 築年数 $t$ に ついても 5 年刻みで設定する必要があるので, 例えば, 築年数 $t=0,1$, $2,3,4$ の建築物については，築年数 $t=0$ で代表させることとした。す なわち, パラメー夕推定時に築年数 $t$ の取りうる值は, $t=0,5,10, \ldots$, 35 となる。

まず, 式(6)の除却率関数 $h_{j}(t)$ の次数を $K=3$ としてパラメー夕 $a_{j k}$ を 推定し注3)，属性別の除却率関数 $h_{j}(t)$ 求めた注4)。その結果を図 1 に 示してある。共同住宅，居宅，併用住宅については，築年数が増す につれて除却率関数の值は大きくなり, 除却のされやすさが年を経 るにつれて徐々に高まることが読み取れる。一方, 工場, その他, 
倉庫等（倉庫・付属建物・車庫）については，除却率関数の築年数 に対する傾きは小さく，除却のされやすさは築年数には強く依存し ていないことが分かる。これらの建築物には，仮設的な建築物や， 逆に, 長期的に利用される建築物が混在するために, 築年数との関 連性は小さく現れていると考えられる。

\section{4 残存確率関数モデルの特徽と応用の可能性}

従来の推定方法文5) で区間残存確率を求め，その結果を図 2 に示 した。また，この区間残存確率をもとに残存確率を求め，図 3 に示 してある。 5 年間 $(\Delta t=5)$ のデー夕をもとに推定してはいるものの, 滑らかでない不連続な形となっていることが分かる。すなわち，従 来の方法で求めた区間残存確率曲線をもとに，個々の建築物の 5 年 後の残存確率（または，除却確率）を推定することは困難である。

推定された区間残存確率関数 $P_{j}(t+5 \mid t)$ を図 4 に示してある。築年 数 $t$ に対して滑らかな曲線となっている。この区間残存確率関数を 用いれば，建築物が 5 年後まで残存する確率を容易に求めることが できる。例えば，築 15 年の共同住宅であれば， 5 年間の残存確率は 約 0.92 であり, 築 30 年の共同住宅であれば約 0.70 であることなど 容易に知ることができる。同様に，残存確率関数 $P_{j}(t)$ を図 5 に示し てある。この残存確率関数 $P_{j}(t)$ を用いれば，例えば，新築された共 同住宅が 15 年後まで，または，30 年後まで残存し続ける確率は， それぞれ約 0.95 , 約 0.55 であることなど, 各用途別の具体的な寿命 特性を読み取ることが可能となる。

本研究では, パラメータ $a_{j k}$ は 5 年ごとに集計したデータを用いて 推定しているが, 残存確率関数モデルは築年数 $t$ の連続関数として 構成してあるので, 任意の築年数 $t$ の残存確率 $P_{j}(t)$, および, 任意 のタイムラグ $\Delta t$ の区間残存確率 $P_{j}(t+\Delta t \mid t)$ を求めることができる。 そのため, 従来のノンパラメトリックな方法よりも応用性が高く, 様々なシミュレーションへ組み込むことが可能である。ここにも残 存確率関数モデルの特徵がある。

\section{3. 地域内建物平均老朽度の推定とその検証 \\ 3.1 地域内建物平均老朽度の推定方法}

前節では，建築物の築年数 $t$ を区間残存確率関数 $P_{j}(t+\Delta t \mid t)$ に代入 することで, 当該建築物が $\Delta t$ 年後まで残存する確率を推定する力法 を示した。この区間残存確率関数の逆関数を構成すれば，区間残存 確率から築年数を推定することが可能となる。具体的には，(1)観測 データから個々の建築物について区間残存確率を推定することはで きないので，ある地域内において $\Delta t$ 年間に観測される建築物の除 却・残存数から当該地域における区間残存確率（地域内区間残存確 率）を推定する。例えば, 観測時点の異なるふたつの数值地図や航 空写真を比較して建築物の除却・残存数を求めれば，地域内区間残 存確率を推定することができる文6)，文》。次に，(2)この推定値を区間 残存確率関数の逆関数に代入すれば，当該地域に存在する建築物の 平均的な老朽度（地域内建物平均老朽度）を推定することができる (区間残存確率関数の逆関数を構成しなくとも, 区間残存確率関数 のグラフ（図 4）をもとに具体的な数值を読み取ってもよい）。

\section{2 地域内建物平均老朽度の推定方法の検証}

東京都 M 市内において観測されたデ一タを用いて, 上記の推定方 法を検証する。1993 年に存在していた用途 $j$ の建築物の数を $N_{j}$, そ の内 5 年後（1998 年）までに除却された建物数を $d_{j}$ とすると, 地

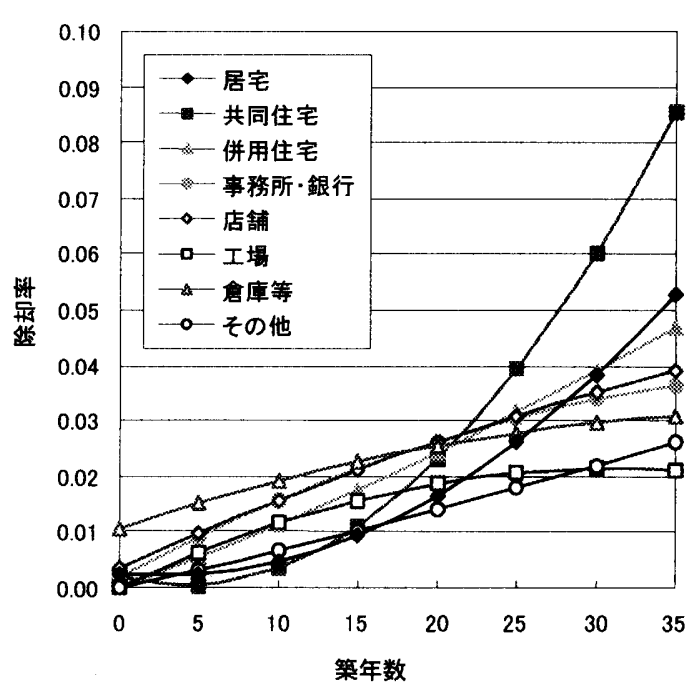

図1：除却率関数

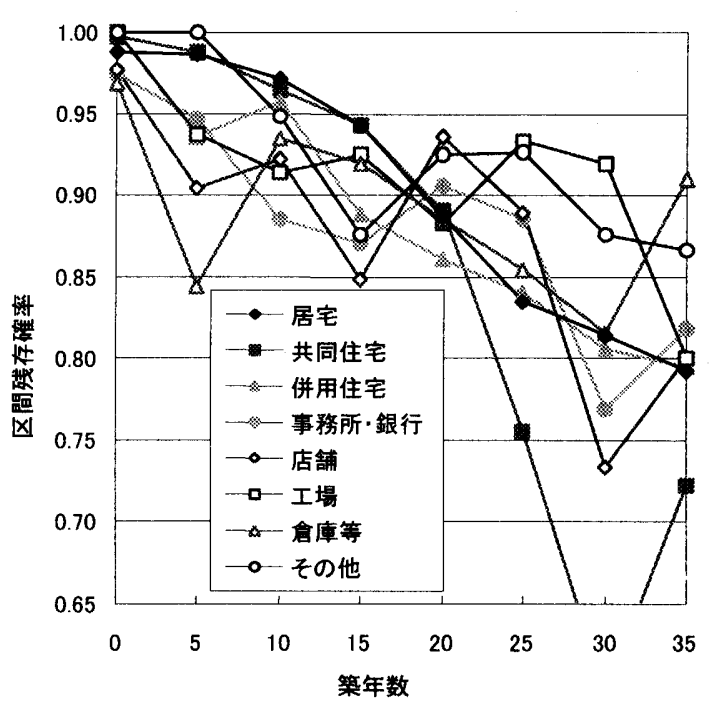

図2: 区間残存確率関数 $(\Delta t=5$, 従来の方法 $)$

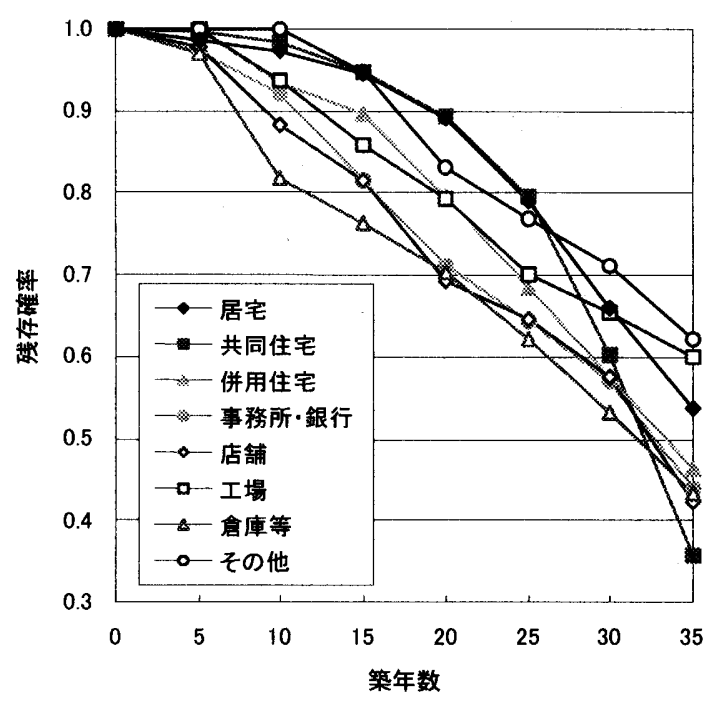

図3: 残存確率関数 (従来の方法) 
域内区間残存確率 $q_{j}$ は，次式を用いて推定することができる。

$$
q_{j}=\frac{N_{j}-d_{j}}{N_{j}}
$$

この地域内区間残存確率 $q_{j}$ の值をもとに上述した方法で地域内建物 平均老朽度 $T_{j}^{*}$ を推定した。一方, 実際の築年数 $t$ をもとに地域内建 物平均老朽度 $T_{j}$ を次式に従い計算した。

$$
T_{j}=\frac{\sum_{t=0}^{n} N_{j}(t) \cdot t}{\sum_{t=0}^{n} N_{j}(t)}
$$

実際の地域内建物平均老朽度 $T_{j}$ とその推定値 $T_{j}^{*}$ との関係を図 6 に示してある。居宅, 共同住宅, 併用住宅については両者の一致の 程度は良好であるが, 工場については，数年以上のずれがある。す なわち, 前章で求めた区間残存確率関数のグラフ（図 4）を見ても 分かるとおり，区間残存確率関数が大きく右下がりの曲線となる場 合には，地域内建物平均老朽度を精度良く推定することが可能であ るが，区間残存確率関数が水平に近い曲線となってしまう場合（除 却率関数の築年数に対する傾きが小さい場合）には, 地域内建物平 均老朽度を高精度で推定することは困難である。本研究では，すべ ての用途について地域内建物平均老朽度を推定することができたが， 場合によっては推定不能となるケースも考えられる。

\section{4. まとめ}

建築物の除却のされやすさを表す除却率関数を築年数の連続関 数として定式化し，これをもとに残存確率関数モデル（残存確率関 数，区間残存確率関数）を導出した。実際の建築物の築年数と除却 · 残存に関するデータを用いて建物用途別にモデル推定を行った。推 定された除却率関数は建物用途によって異なり，築年数が除却要因 として強く作用する用途とそうでない用途が存在することが判明し た。残存確率関数モデルは築年数の連続関数として構成しているこ とから, 従来の方法よりも灾用性が高いことを示した。さらに, 残 存確率関数モデルの具体的な応用例として，2 時点間で観測される 除却・残存建物の数から地域内の平均的な老朽度（地域内建物平均 老朽度）を推定する方法を示した。

本稿では，区間残存確率関数は分析対象地域全体で一様と考えた が，堤ら文4)が指摘しているように，地域性にも依存していると考え られる。区間残存確率関数の地域性に関する検討と, より小さな空 間単位での地域内平均建物老朽度の推定精度に関する検証は，今後 の課題としたい。

本稿は，文献 9)をもとに，新たに分析を加え，加筆修正したもので ある。

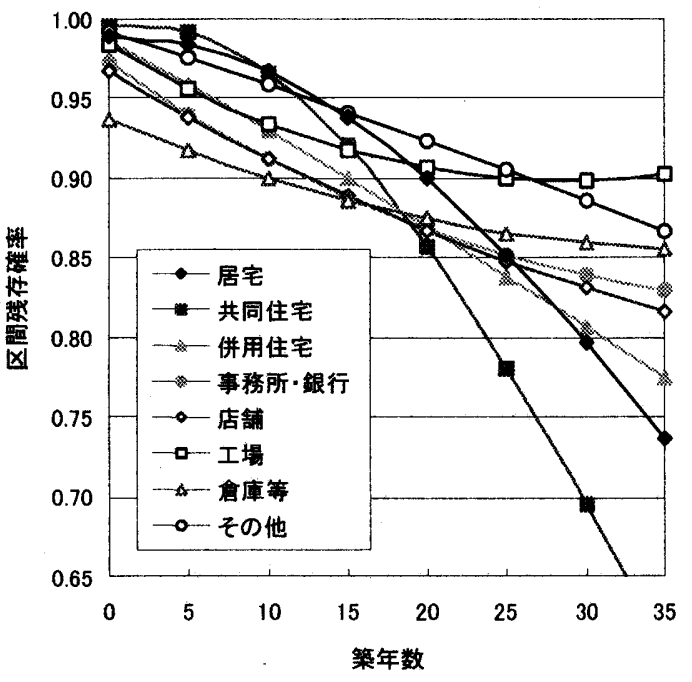

図4：区間残存確率関数 $(\Delta \mathrm{t}=5)$

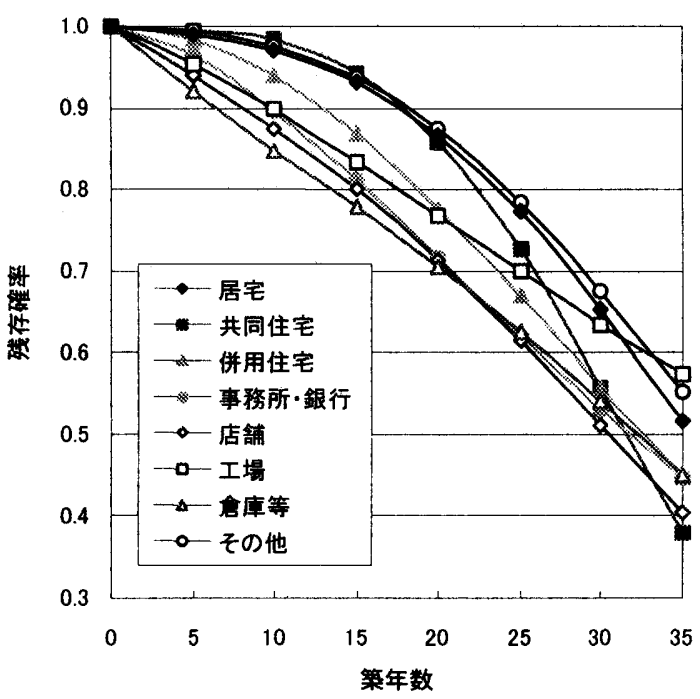

図5: 残存確事関数

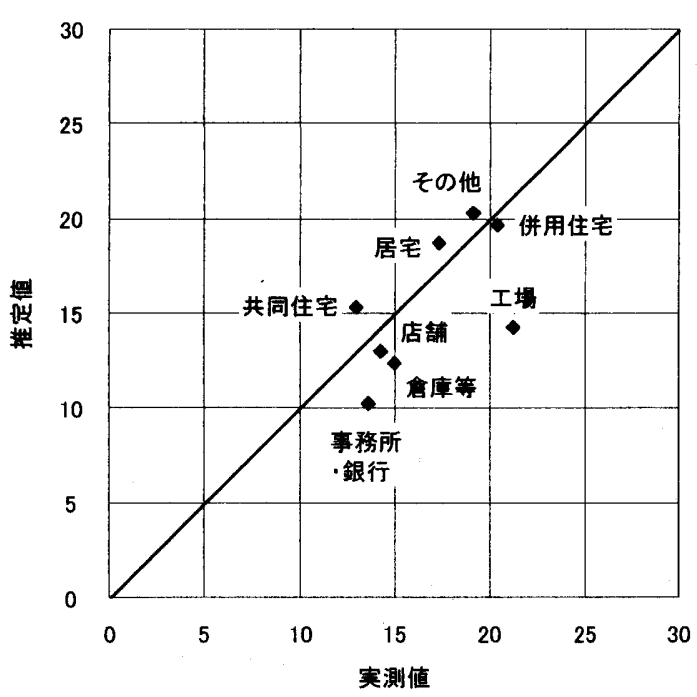

図6：地域内建物平均老朽度の実測地と推定值 
1) ラグランジュ関数は以下のように書くことができる。

$$
\begin{aligned}
L\left(a_{j k}, \lambda_{j t}\right)= & \sum_{j=1}^{m} \sum_{t=1}^{n} d_{j}(t) \ln \left\{1-\exp \left[-\sum_{k=1}^{K} a_{j k}\left\{(t+1)^{k}-t^{k}\right\}\right]\right\} \\
& +\sum_{j=1}^{m} \sum_{t=1}^{n}\left\{N_{j}(t)-d_{j}(t)\right\}\left[-\sum_{k=1}^{K} a_{j k}\left\{(t+1)^{k}-t^{k}\right\}\right] \\
& +\sum_{j=1}^{m} \sum_{t=1}^{n} \lambda_{j k} \sum_{k=1}^{K} k a_{j k} t^{k-1}
\end{aligned}
$$

ここで, パラメータ $\lambda_{j t}$ はラグランジュの未定乗数である。すなわち, パラ メータ $a_{j k}$ は次の微分方程式を解くことで推定することができる。

$$
\frac{\partial L\left(a_{j k}, \lambda_{j t}\right)}{\partial a_{j k}}=\frac{\partial L\left(a_{j k}, \lambda_{j t}\right)}{\partial \lambda_{j t}}=0
$$

2) 式(A1)に示したラグランジュ関数 $L\left(a_{j k}, \lambda_{j i}\right)$ の $a_{j k}$ に関する1階微分，および， 2 階微分は，それぞれ以下のとおりである。

$$
\begin{aligned}
& \frac{\partial L\left(a_{j k}, \lambda_{j t}\right)}{\partial a_{j k}}=\sum_{t=1}^{n}\left\{(t+1)^{k}-t^{k}\right\} \\
& \left\{\frac{N_{j}(t) \exp \left[-\sum_{r=1}^{K} a_{j r}\left\{(t+1)^{r}-t^{r}\right\}\right]-N_{j}(t)+d_{j}(t)}{1-\exp \left[-\sum_{r=1}^{K} a_{j r}\left\{(t+1)^{r}-t^{r}\right\}\right]}+\lambda_{j t} k t^{k-1}\right\}
\end{aligned}
$$

$$
\begin{aligned}
& \frac{\partial^{2} L\left(a_{j k}, \lambda_{j t}\right)}{\partial a_{j k} a_{j k^{\prime}}}= \\
& \sum_{t=1}^{n} \frac{\left.-d_{j}(t)\left\{(t+1)^{k}-t^{k}\right\}(t+1)^{k^{\prime}}-t^{k^{\prime}}\right\} \exp \left[-\sum_{r=1}^{K} a_{j r}\left\{(t+1)^{r}-t^{r}\right\}\right]}{1-\exp \left[-\sum_{r=1}^{K} a_{j r}\left\{(t+1)^{r}-t^{r}\right\}\right]}<0
\end{aligned}
$$

3）次数 $K$ を大きくとりすぎるとわずかなデータのゆらぎまでも記述される ことになり，結果的に不自然な関数が得られてしまう。そこで，ここでは $K=3$ とした。後述するように， $K=3$ としても従来の方法で求めた残存確率 曲線を忠実に近似することができる。

4）パラメータの推定には Gauss 統計数值解析システム（オプション： Constrained Optimization) を用いた。また，式(11)を満足しながら対数尤度 $\ln P$ の最大化を図る数値計算プログラムを作成し，闭者の推定值を比較する ことで推定パラメータの良好な推定精度を確認している。

\section{考文献}

1）谷口沉邦，天野克也：既存建筑物の更新実態とその変容に関わる物的条件 について 一大都市既成住宅・市街地における建築・空間の変容に関する 基礎的研究 その 1 -, 第 18 回日本都市計画学会学術研究発表会論文集, pp. $277 \sim 282, \quad 1983$

2）小松幸夫：建物寿命の年齢別データによる推計に関する基磷的考察，日本 建築学会計画系論文報告集 No.439，pp.91～99，1992.9

3）小松幸夫・加藤裕久・吉田倬郎・野城智也：わが国における各種住宅の寿 命分布に関する調查報告 -1987 年固定資産台帳に基づく推計一，日本建 築学会計画系論文報告集 No.439, pp.101 110，1992.9

4）堤洋樹，小松幸夫：1980 年以降における木造尃用住宅の寿命推移，日本 建築学会計画系論文集 No.580,pp.169 174，2004.6

5）大佛俊泰, 清水貴雄: 建築物の除却関連因子と残存確率曲線の推定, 日本 建築学会計画系論文集 No.560，pp.201 206，2002.10

6）伊藤香織, 曲㴊英邦 : 既存情報を活用した時空間デー夕作成手法 一地図 内・地図外情報の䁔昧性を考虑した空間要素同定を用いて一，地理情報シ ステム学会講演論文集, vol.10, pp.147 150，2001.10

7) 三浦昌生，八講朋子：住宅の築年数調査による建て替えが必要な地区の抽 出, 日本建築学会大会学術講演梗概集 D-1, pp.989 990, 1997.9

8）市田崇，鈴木和幸：信頼性の分布と統計、日科技連，1984

9）大佛俊泰: 建築物の除却率関数の定式化上推定, 日本建築学会大会学術講 演梗概集 F-1，pp.465 466，2004.8 